Hal.

\title{
PRODUKSI IgA \& IgG MUKOSAL DAN SISTEMIK SETELAH IMUNISASI PER ORAL DENGAN PROTEIN Adh036 SALMONELLA TYPHI PADA MENCIT BALB/C
}

\section{(THE PRODUCTION OF MUCOSAL AND SYSTEMIC IgA AND IgG AFTER ORAL IMMUNIZATION WITH AdhO36 PROTEIN SALMONELLA TYPHI ON BALB/C MICE)}

\author{
Sanarto Santoso \\ Laboratorium Mikrobiologi Fakultas Kedokteran Universitas Brawijaya
}

\begin{abstract}
An experiment has been conducted to determine the production of mucosal and systemic IgA and IgG after oral immunization with AdhO36 protein Salmonella typhi using CTB as adjuvant. The results of ELISA Test, shows that AdhO36 protein Salmonella typhi were highly significantly $(p=0.001)$ able to induce the production of $S-\lg A$ (secretory $\lg A)$, as compared to control and CTB treatment. The analysis of variance results show that the effect of AdhO36 protein to the IgA content in serum is high significantly different to IgA content in mucus ( $p=0.001)$. This finding is relevant to the previous experiments that the oral administration of AdhO36 protein can inhibit the in vivo adhessive process of Salmonella typhi at enterocytes of Balb/c mice. Therefore, it can be concluded that AdhO36 protein Salmonella typhi is a potential mucosal immunogen which can induce mucosal immune response as the results of the formation of protective S-IgA, which in turn, can inhibit the adhesive process as the initial stage of infection process at enterocytes of Balb/c mice. Apart from S-IgA, in this experiment AdhO36 protein Salmonella typhi can also induce IgG serum. The analysis of variance results show that the effect of AdhO36 protein to the $\mathrm{IgG}$ content in serum is high significantly different to $\lg \mathrm{G}$ content in mucus ( $p=0.001$ ). It can then be concluded that the oral administration of AdhO36 protein as an immunogen, is not only able to stimulate the mucosal humoral immune response, but can also stimulate the systemic humoral immune response on Balb/c mice.
\end{abstract}

Key words : S-IgA, IgG, AdhO36 protein, Salmonella typhi

\section{ABSTRAK}

Telah dilakukan penelitian untuk mengetahui produksi IgA dan IgG mukosal dan sistemik setelah imunisasi per oral protein AdhO36 Salmonella typhi dengan ajuvan CTB pada mencit Balb/c. Hasil dari penelitian ini dengan menggunakan uji ELISA membuktikan bahwa protein AdhO36 Salmonella typhi mampu menginduksi S-IgA(secretory IgA) yang sangat bermakna ( $p=0,001)$ bila dibandingkan dengan kontrol dan perlakuan CTB. Hasil Anova pengaruh perlakuan terhadap kadar IgA dalam serum dan mukus untuk protein Adh036 menunjukkan bahwa rerata kadar IgA dalam mukus berbeda sangat bermakna dengan rerata kadar IgA dalam serum $(p=0,001)$. Dari penelitian terdahulu telah dapat dibuktikan bahwa protein AdhO36 pada pemberian per oral dapat menghambat proses adhesi in vivo Salmonella typhi pada enterosit mencit Balb/c. Dengan demikian dapat disimpulkan bahwa protein Adh036 Salmonella typhi merupakan imunogen mukosal poten yang mampu membangkitkan respons imun mukosal dengan terbentuknya S-IgA protektif yang dapat menghambat proses adhesi sebagai tahap awal proses infeksi, pada enterosit mencit Balb/c. Selain S-IgA, pada penelitian ini protein AdhO36 Salmonella typhi dapat juga menginduksi IgG serum. Hasil Anova pengaruh perlakuan terhadap kadar IgG dalam serum dan mukus untuk protein AdhO36 menunjukkan bahwa rerata kadar IgG dalam serum berbeda sangat bermakna dengan rerata kadar Ig $G$ dalam mukus $(p=0,001)$. Dengan demikian protein AdhO36 sebagai imunogen yang diberikan per oral tidak hanya mampu merangsang respons imun humoral mukosal, namun dapat juga merangsang respons imun humoral sistemik pada mencit Balb/c.

Kata kunci : S-IgA, IgG, protein Adh036 Salmonella typhi

\section{PENDAHULUAN}

Demam tifoid sebagai penyakit sistemik yang disebabkan oleh Salmonella typhi sampai saat ini masih merupakan problem kesehatan, utamanya di negara-negara yang sedang berkembang termasuk Indonesia. Hal ini disebabkan oleh karena berbagai faktor, salah satunya ada vaksin yang benar-benar efektif (1). Pada umumnya penderita yang berhasil mengatasi demam tifoid akan mendapatkan kekebalan terhadap infeksi ulangan; meskipun insiden terkena kekambuhan bisa terjadi sekitar $2-3 \%$ bila seseorang terpapar kembali dengan inokulum bakteri yang sangat tinggi atau mendapatkan terapi antibiotika pada awal penyakit (2).

Kontak pertama antara Salmonella spp. dengan sistem imun hospes terjadi pada level mukosa usus, kemungkinan hal ini terjadi melalui intervensi langsung akibat proses adhesi, invasi, dan multiplikasi di dalam mukosa (3). Secretory IgA (S$\operatorname{lgA}$ ) antibodies dilaporkan protektif pada mencit yang secara oral diinfeksi dengan Salmonella typhimurium virulen (4).

Beberapa bukti menunjukkan bahwa infeksi Salmonella typhi pada manusia menginduksi respons imun humoral dan seluler (5). Antibodi yang beredar dalam sirkulasi ditujukan

Maj. Kedok. Unibraw Vol. XIX, No.2, Agustus 2003 
Hal.

kepada LPS dan flagella. Sedangkan respons imun terhadap ViPS (kapsul polisakarida) sangat rendah kecuali pada chronic typhoid carriers (6). Disamping itu didapatkan juga respons serum antibodi yang bermakna terhadap antigen protein Salmonella typhi yang termasuk specific outer membrane protein (7).

Materi yang menjadi subyek penelitian adalah protein adhesin OMP (outer membrane protein) bakteri Salmonella typhi. Dari penelitian pendahuluan diketahui memiliki berat molekul $36 \mathrm{kD}$, protein adhesin OMP $36 \mathrm{kD}$ ini kemudian diberi nama protein AdhO36.

Molekul adhesin yang berpotensi imunogenik dapat digunakan sebagai komponen vaksin mukosal untuk tujuan mencegah terjadinya penyakit infeksi. Vaksin mukosal berupa molekul adhesin ini akan memberikan serangan ganda pada bakteri, yaitu melalui antibodi yang akan menghambat perlekatan dan memberi tanda pada bakteri untuk dihancurkan oleh sistem imun (8). Hambatan pada proses perlekatan bakteri Salmonella typhi pada sel epitel usus dapat dimanfaatkan di dalam usaha pencegahan penyakit demam tifoid yang saat ini masih merupakan masalah penyakit infeksi yang harus diatasi. Dari penelitian terdahulu telah terbukti bahwa imunisasi per oral protein Adh036 mampu menghambat proses adhesi in vivo Salmonella typhi pada enterosit mencit Balb/c (9).

Keuntungan yang penting dari pengembangan vaksin mukosal adalah kecenderungan untuk menginduksi baik respons imun mukosal maupun sistemik. Karena pertahanan humoral spesifik diperankan oleh antibodi serum dan antibodi sekresi terutama IgA, maka peningkatan dan pengembangan vaksin ke depan dibutuhkan vaksin yang mampu menginduksi keduanya baik respons imun mukosal maupun sistemik. Kemampuan vaksin seperti itulah yang saat ini menjadi pusat perhatian pengembang vaksin (10).

Tujuan dari penelitian ini adalah membuktikan bahwa protein adhesin yang berasal dari OMP yang diberi nama protein Adh036 Salmonella typhi tersebut apabila diberikan per oral bersifat imunogenik dan mampu menginduksi respons imun humoral baik mukosal maupun sistemik pada hewan coba mencit Balb/c.

\section{MATERI DAN METODA}

\section{Bakteri:}

Salmonella typhi diperoleh dari spesimen klinis penderita demam tifoid di R.S.Dr.Saiful Anwar Malang. Kultur bakteri menggunakan prosedur yang biasa dilakukan di laboratorium Mikrobiologi FK Unibraw dan identifikasi bakteri dilakukan dengan Microbact System.

\section{Bahan dan Reagensia:}

MacConkey agar, BSA, TCG agar, BHI broth, Trichloroacetic acid (TCA), Phosphat Buffer Saline (PBS), EGTA, dithiothreitol, bahan \& reagens untuk elektroforesis SDS-PAGE, Sephacryl HR-100, detergent untuk OMP: Chaps [3-\{(3Cholamydopropyll)-dimethyl-ammonio\}-1-prophanesulfonate] (Sigma Ultra), Ajuvan: CTB, Microbact System, bahan pewarnaan Gram.

\section{Hewan Coba:}

Mencit betina galur Balb/c, berat sekitar 25 gram, umur sekitar 8 minggu, yang diperoleh dari Pusvetma-Wonocolo, Surabaya.

Alat:

Sentrifus biasa, sentrifus dingin, alat pemotong pili omnimixer, inkubator, timbangan elektrik, shaker incubator, alat elektroforesis SDS-PAGE, kolom untuk kromatografi gel.

\section{Perbanyakan bakteri:}

Setelah dilakukan identifikasi Salmonella typhi, bakteri isolat diperbanyak pada medium MacConkey diinkubasikan pada suhu $37^{\circ} \mathrm{C}$ selama $18-24$ jam. Biakan dari medium MacConkey ini kemudian dipindahkan kedalam medium biphasic yang terdiri atas medium cair BHI dan medium agar miring TCG, diinkubasikan pada suhu $37^{\circ} \mathrm{C}$ selama 24 jam $(11,12)$.

\section{Pemisahan bagian sel dari fimbriae:}

Biakan cair dari medium biphasic dipindahkan kedalam tabung sentrifus $100 \mathrm{cc}$, ditambahkan TCA sehingga konsentrasinya $3 \%$, kemudian diputar pada sentrifus dingin $4^{\circ} \mathrm{C}$ 6000 rpm selama 15 menit. Endapan disuspensi dengan PBS pH 7,4 secukupnya, kemudian dilakukan pemotongan fimbriae menggunakan alat omnimixer pada suhu $4^{\circ} \mathrm{C}(12,13)$. Sampel kemudian diputar dalam sentrifus dingin $4^{\circ} \mathrm{C} 12.000 \mathrm{rpm}$ selama 15 menit. Filtrat dipisahkan (mengandung fraksi fimbriae) dan endapan disuspensi dengan PBS pH 7,4 secukupnya, kemudian dilakukan pemotongan fimbriae lagi. Proses ini diulangi sampai kira-kira 7 kali dan dihentikan setelah terlihat perbedaan pola protein yang jelas antara fraksi fimbriae dengan fraksi sel (dilakukan elektroforesis). Dari prosedur ini, diperoleh endapan yang merupakan bagian sel bakteri dan digunakan untuk fraksinasi OMP

\section{Fraksinasi OMP:}

Bagian sel dari prosedur diatas, disuspensi dengan PBS pH 7,4 secukupnya, kemudian ditambahkan Chaps (3-\{(3Cholamidopropyl)-dimethyl-ammonio\}-1-propanesulfonate).

sehingga diperoleh kadar $0,5 \%(\mathrm{~b} / \mathrm{v})$. Dikocok menggunakan vortex selama 5 menit, kemudian diputar pada sentrifus dingin $4^{\circ} \mathrm{C} 12.000 \mathrm{rpm}$ selama 15 menit. Filtrat diambil, dilakukan dialisis menggunakan PBS pH 7.4 untuk menghilangkan Chaps. Kemudian dialisat diendapkan dengan ammonium sulfat $35 \%$, disentrifus pada $4^{\circ} \mathrm{C} 6000 \mathrm{rpm}$ selama 15 menit. Filtrat dibuang, endapan disuspensi dengan PBS secukupnya dan dilakukan dialisis kembali. Dialisat disimpan sebagai fraksi OMP (14).

\section{Preparasi antigen :}

Yang disebut antigen dalam hal ini adalah protein Adhesin-036 (Adh036). Untuk pemurnian protein antigen dipakai metode khromatografi gel menggunakan Sephacryl HR-100. Sebagai washing solution dipakai TEA dan sebagai eluen adalah TEAN. Hasil eluat khromatografi dielektroforesis SDS-PAGE menurut metode Laemli (1970) (15). Kemudian pita protein pada posisi berat molekul sekitar $36 \mathrm{kDa}$ dipotong dan dikumpulkan, selanjutnya dilakukan elektroelusi sehingga diperoleh endapan kering protein yang dimaksud. 
Hal.

\section{Pemeriksaan Produksi Antibodi (Metoda ELISA)}

Parameter yang diamati pada pemeriksaan antibodi ini adalah kadar $\lg G$ dan IgA di dalam serum dan di dalam mukus.

Dalam uji ini menggunakan 3 kelompok, yaitu: 1) perlakuan kontrol, mencit tidak diberi imunisasi; 2) perlakuan CTB, mencit diimunisasi dengan CTB $7 \mu \mathrm{g} / 0.3 \mathrm{ml}$ PBS per mencit; 3) perlakuan protein adhesin-O36 (AdhO36), mencit diimunisasi dengan CTB + protein Adh036 $250 \mu \mathrm{g} / 0.3 \mathrm{ml} \mathrm{PBS}$. Sebelum diberi perlakuan, masing-masing mencit diberi larutan natrium bikarbonat $0,2 \mathrm{M}$ sebanyak $0,3 \mathrm{ml}$. Semua perlakuan ini diberikan per oral. Imunisasi diberikan 4 kali selang satu minggu, dan pada akhir minggu ke 4 mencit dimatikan, diambil serum dan mukusnya. Sampel serum dan sampel mukus dikumpulkan dari setiap 2 mencit sebagai pooled serum dan pooled mucus. Preparasi sampel serum dilakukan seperti pada Uji Imunogenisitas, sedangkan preparasi mukus adalah sebagai berikut: potongan usus dicuci dengan PBS dingin yang mengandung protease inhibitor $(25 \mu \mathrm{g} / \mathrm{ml}$ inhibitor cocktail) dan 1,0 mM EDTA, kemudian usus dibuka sehingga terlihat bagian mukosa usus halus. Lapisan mukus diambil dengan cara scraping secara longitudinal menggunakan spatel dan ditampung di dalam tabung yang berisi PBS steril dan protease inhibitor. Suspensi dikocok, kemudian disentrifus $12,000 \mathrm{rpm}$ pada $4^{\circ} \mathrm{C}$ selama 10 menit. Supernatan diambil, dilakukan pemurnian seperti pada pemurnian serum dan digunakan sebagai sampel mukus untuk pemeriksaan S-IgA (secretory $\lg A$ ) dan IgG dengan metode ELISA (16).

\section{HASIL}

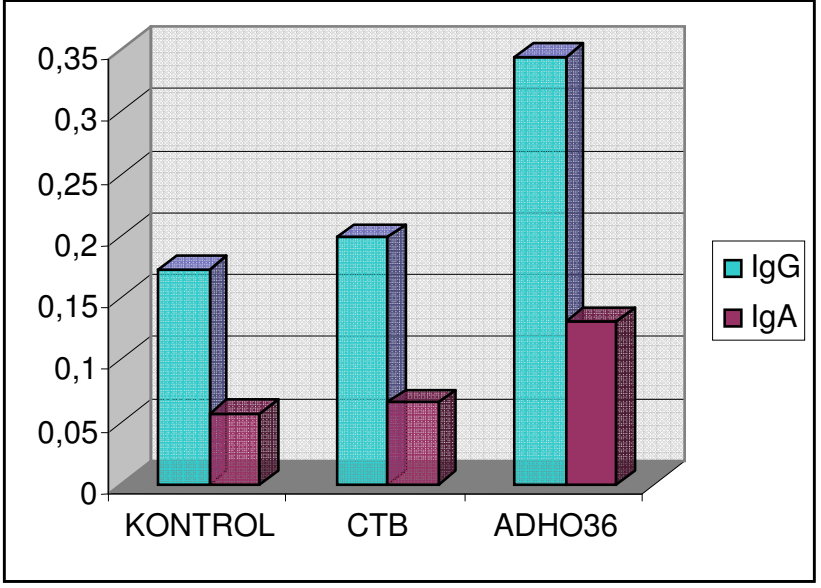

Gambar 1. Hasil rerata ELISA serum pasca imunisasi per oral dengan Protein Adh036

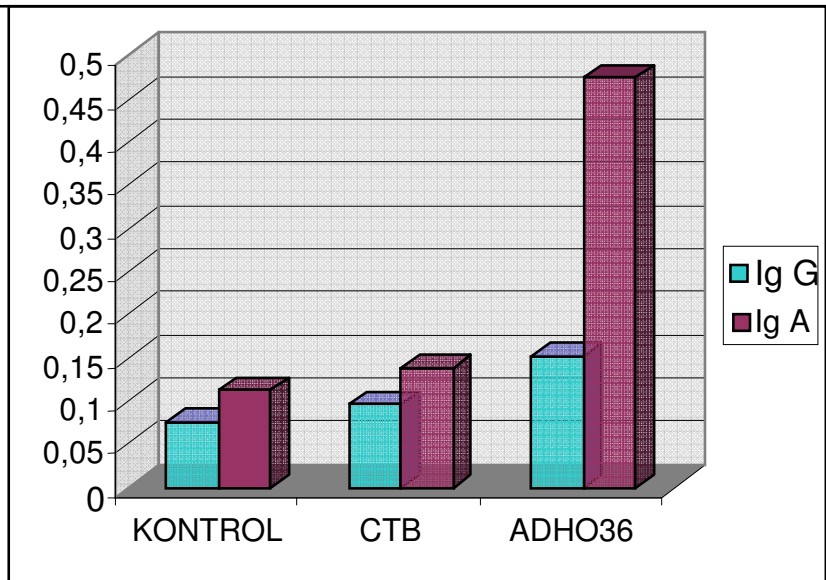

\section{Gambar 2. Hasil rerata ELISA mukus pasca imunisasi per oral dengan Protein Adh036}

Gambar 1 dan Gambar 2 masing-masing menunjukkan rerata hasil Uji ELISA tentang kadar IgG dan IgA dalam serum dan mukus terhadap protein Adh036 setelah perlakuan, dengan pengulangan 4 kali. Tampak bahwa protein AdhO36 mampu menginduksi IgG serum dan $\lg A$ mukosal (S-lgA) dalam konsentrasi yang tinggi.

Hasil Anova pengaruh perlakuan terhadap kadar IgG dalam serum dan mukus untuk protein AdhO36 menunjukkan bahwa rerata kadar IgG dalam serum berbeda bermakna dengan rerata kadar Ig $G$ dalam mukus $(p=0.001)$. Pengaruh perlakuan terhadap kadar lgG dalam mukus tidak berbeda bermakna $(p=0.059)$, tetapi berbeda bermakna pada kadar $\lg G$ dalam serum $(p=0.012)$.

Hasil Anova pengaruh perlakuan terhadap kadar IgA dalam serum dan mukus untuk protein AdhO36 menunjukkan bahwa rerata kadar IgA dalam mukus berbeda bermakna dengan rerata kadar IgA dalam serum $(\mathrm{p}=0.001)$. Pengaruh perlakuan terhadap kadar IgA dalam serum tidak berbeda bermakna $(p=0.447)$, tetapi pengaruh perlakuan berbeda bermakna pada kadar IgA dalam mukus $(p=0.001)$. Hasil Tukey's test disajikan seperti pada tabel 1 dan 2

Tabel 1. Hasil Tukey's test Pengaruh Perlakuan terhadap Kadar IgG Serum untuk Protein Adh036

\begin{tabular}{|c|c|}
\hline Perlakuan & Rerata \\
\hline \hline Kontrol & $0.173 \mathrm{a}$ \\
\hline CTB & $0.199 \mathrm{a}$ \\
\hline AdhO36 & $0.346 \mathrm{~b}$ \\
\hline
\end{tabular}

Keterangan:

Nilai rerata yang didampingi huruf yang sama berarti tidak berbeda bermakna dengan $p=0.05$ dan nilai $\mathrm{HSD}=0.163$ 
Hal.

Tabel 2. Hasil Tukey's test Pengaruh Perlakuan terhadap Kadar IgA dalam Mukus untuk Protein Adh036

\begin{tabular}{|c|c|}
\hline Perlakuan & Rerata \\
\hline \hline Kontrol & $0.112 \mathrm{a}$ \\
\hline CTB & $0.135 \mathrm{a}$ \\
\hline AdhO36 & $0.475 \mathrm{~b}$ \\
\hline
\end{tabular}

Keterangan:

Nilai rerata yang didampingi huruf yang sama berarti tidak berbeda bermakna dengan $p=0.05$ dan nilai $B N J=0.168$

\section{PEMBAHASAN}

Guna menghindari oral tolerance dimana sistem imun mukosal menjadi tidak responsif terhadap imunogen oral, maka protein atau imunogen tersebut harus dikonyugasikan dengan ajuvan tersebut misalnya cholera toxin (CT) atau cholera toxin subunit-B (CTB) dan LT dari E.coli $(17,18)$. Sebenarnya banyak bahan lain yang dapat digunakan sebagai ajuvan mukosal dari penelitian-penelitian selanjutnya, antara lain yang berasal dari bagian bakteri ialah LPS, yang berasal dari toxin bakteri selain CT dan LT Pertussigen, Clostridium difficile toxins, Shiga toxin dan Staphylococcal enterotoxins, tetapi kelihatannya semua memberikan efek toksik. Bahan sintetis yang dapat digunakan sebagai ajuvan mukosal adalah Quil $A$, suatu komponen dari saponin, bahan deterjen yang berasal dari tumbuhan Quillaja saponaria Molina. Penggunaan Quil A sebagai ajuvan terbatas karena efek toksiknya, namun telah dapat diidentifikasi fraksi QuilA yang nontoksik dan sekarang digunakan sebagai salah satu komponen dari ISCOM (Immunostimulating Complexes). Selain itu, ada juga sitokin yang memiliki aktivitas ajuvan, di antaranya adalah IL-12. Pada pemberian oral, IL-12 memberikan respons yang kurang-lebih sama dengan pemberian parenteral, namun respons IgA mukosal tampaknya tidak terpengaruh. Kelihatannya, IL-12 bila diberikan peroral dengan antigen akan menimbulkan respons Th1 yang akan memberikan proteksi terhadap patogen intraseluler. Sedangkan IL-13 bila diberikan dalam vaksin mukosal tampaknya dapat meningkatkan respons Th2, tetapi hipotesis ini perlu diuji lebih lanjut (18).

Pada percobaan ini digunakan CTB sebagai ajuvan sekaligus sebagai protein carrier untuk protein Adh036. Digunakannya CTB sebagai ajuvan pada percobaan ini antara lain karena (1) CTB merupakan salah satu ajuvan yang poten yang sering digunakan, (2) CTB bisa diterima dengan baik oleh traktus gastro intestinalis, dan stabil pada suasana asam, (3) CTB bertanggung jawab pada pengikatan dengan reseptor $\mathrm{G}_{\mathrm{M} 1}$ yang terdapat pada semua sel berinti termasuk epitel usus, dan (4) CTB tidak toksik, terutama apabila vaksin ini akan dicobakan kepada manusia (19).

Dari hasil Anova pengaruh perlakuan terhadap kadar IgG dalam serum dan mukus untuk protein AdhO36, menunjukkan bahwa rerata kadar IgG di dalam serum berbeda sangat bermakna dengan rerata kadar IgG mukus $(p=0.001)$. Pengaruh perlakuan terhadap kadar IgG dalam mukus tidak berbeda bermakna $(p=0.059)$, sedangkan pengaruh perlakuan terhadap kadar IgG dalam serum berbeda bermakna $(p=0.012)$. Dari hasil Tukey's test tentang pengaruh perlakuan terhadap kadar IgG serum untuk protein AdhO36 (Tabel 1) menunjukkan bahwa terdapat perbedaan yang sangat bermakna antara perlakuan kontrol dan CTB dengan perlakuan Adh036. Hal ini menunjukkan bahwa kadar IgG dalam serum lebih tinggi dari kadar IgG dalam mukus terhadap protein AdhO36 sebagai antigen. Hal ini sesuai dengan teori yang ada tentang estimasi produksi IgG pada manusia dewasa sehat, dimana kadar IgG dalam sirkulasi (sekitar $2100 \mathrm{mg}$ ) lebih tinggi dari pada kadar IgG dalam usus kecil (sekitar $590 \mathrm{mg}$ ) per hari (20). Dengan demikian maka kelihatannya pada percobaan ini, IgG sebagai respons imun mukosal terhadap protein AdhO36 sedikit sekali yang disekresikan ke dalam lumen usus.

Pada Anova pengaruh perlakuan terhadap kadar IgA di serum dan mukus untuk protein AdhO36, menunjukkan bahwa rerata kadar IgA dalam serum berbeda sangat bermakna dengan rerata kadar IgA dalam mukus $(p=0.001)$. Pengaruh perlakuan terhadap kadar IgA di dalam serum tidak berbeda bermakna $(p=$ 0.447), sedangkan pengaruh perlakuan terhadap kadar $\operatorname{lgA}$ dalam mukus berbeda sangat bermakna $(p=0.001)$. Dari hasil Tukey's test tentang pengaruh perlakuan terhadap kadar IgA mukus untuk protein AdhO36 (Tabel 2) menunjukkan bahwa terdapat perbedaan yang sangat bermakna antara perlakuan kontrol dan CTB dengan perlakuan AdhO36. Dengan demikian menunjukkan bahwa kadar IgA yang terbentuk dalam serum sangat sedikit, sebaliknya yang disekresikan dalam mukus sangat banyak. Hal ini telah jelas diketahui bahwa IgA pada sekresi mukosal berada dalam konsentrasi yang lebih tinggi dibandingkan dengan imunoglobulin yang lain; bisa mencapai lebih dari 3 gr per hari pada manusia dewasa sehat (21).

Melihat pengaruh perlakuan terhadap kadar IgG dalam serum yang lebih besar dari pada kadar IgG dalam mukus untuk Adh036 serta melihat pengaruh perlakuan terhadap kadar S-IgA (IgA dalam mukus) yang lebih besar dari pada kadar IgA dalam serum untuk Adh036, maka hal ini sesuai dengan respons imun humoral normal. Kadar IgG dalam serum memang lebih tinggi dibandingkan dengan IgG dalam sekresi usus, demikian pula kadar IgA dalam sekresi usus memang lebih tinggi dari pada IgA dalam serum (21). Dengan demikian maka protein AdhO36 dengan dosis $250 \mu \mathrm{g}$ dan $7 \mu \mathrm{g}$ CTB (perlakuan AdhO36) telah menunjukkan potensinya untuk menginduksi IgG dalam serum dan IgA dalam mukus yang tinggi. Pada penelitian yang lain yang menggunakan tetanus toxoid sebagai antigen sebanyak $250 \mu \mathrm{g}$ dan $10 \mu \mathrm{g}$ CT yang diberikan secara per oral $3 \mathrm{x}$ dengan interval 1 minggu dapat menginduksi IgA di tinja dan IgG di dalam serum yang tinggi (22). Juga penelitian yang menggunakan $200 \mu \mathrm{g}$ protein solubel HEL (hen egg lysozyme) dan $5-10 \mu \mathrm{g}$ CT yang diberikan $2 \times$ dengan interval 3 minggu dapat menginduksi respons IgG, IgA dan IgE intestinal (23).

Gabungan protein AdhO36 dan CTB yang diberikan secara oral pada mencit, akan masuk melalui sel $\mathrm{M}$ untuk ditangkap oleh APC. APC melalui jalur MHC-II akan menyajikan peptida kepada sel $\mathrm{T} \mathrm{CD4}^{+}$kemudian mengaktifkannya untuk selanjutnya berinteraksi dengan sel $\mathrm{B} / \mathrm{lgM}$ dan menginduksi class-switching menjadi sel B/lgA dibawah pengaruh TGF- $\beta$ dan IL-5; yang semuanya terjadi dalam Peyer's patch. Sel B/lgA akan masuk ke lamina propria melalui mesenteric lymph node (MLN) untuk menjadi sel plasma dibawah pengaruh CD40L, IL-5 dan IL- 
Hal.

6, yang akan mensintesa polymeric/dimeric $\lg A$. Dimeric $\lg A$ berikatan dengan poly $\mathrm{lg}$ receptor (secretory component=SC) pada membran basolateral sel epitel mukosa. Kompleks ini ditransportasikan secara aktif melintas sel epitel mukosa dan dilepaskan melalui pemecahan proteolitik ke dalam lumen sebagai S-lgA $(17,24,25)$

Sistem yang baik ini memberikan immune exclusion pada permukaan mukosa, yaitu mencegah masuknya patogen baru melalui pertahanan mukosa. Di samping itu, transitosis memberikan immune elimination yang terdiri atas transpor aktif ikatan IgA-patogen baik dari stroma maupun epitel menuju lumen digestif, serta membuat patogen menjadi inaktif sebelum dilepaskan (26). Alasan yang memungkinkan, mengapa IgA diproduksi lebih banyak dalam sistem imun mukosal dibandingkan jaringan yang lain, karena isotype switching ke IgA terjadi paling efisien dalam jaringan limfoid mukosal; di samping itu sel Th2 yang memproduksi IL-5 lebih banyak dalam mukosa dibandingkan dalam jaringan limfoid yang lain. Sel B yang memproduksi IgA juga mempunyai kecenderungan untuk homing ke jaringan mukosal (24).

Adanya IgG dalam serum menunjukkan bahwa protein Adh036 sebagai antigen yang diberikan per oral tidak hanya mampu merangsang respons imun mukosal, namun juga mampu merangsang respons imun humoral secara sistemik. Hal ini terjadi karena kemungkinan ada sebagian sel APC mukosal yang telah menangkap protein AdhO36+CTB langsung masuk ke dalam peredaran darah dan menginduksi respons imun sistemik sehingga terbentuk IgG serum. Dengan demikian, apabila setelah vaksinasi oral, masih ada Salmonella typhi yang berhasil lolos dari S-lgA, dan masuk peredaran darah maka akan berhadapan dengan IgG serum. Tampaknya protein AdhO36 ini dapat diandalkan sebagai kandidat vaksin oral yang bisa memberikan proteksi baik mukosal maupun sistemik, namun hal ini perlu penelitian lebih lanjut, khususnya mengenai protektivitas respons imun sistemik.

Mengenai respons serum antibodi ini telah dipelajari secara ekstensif dengan vaksin Ty21a yang sekarang telah dikemas dalam bentuk kapsul enteric coated. Penggunaan vaksin oral Ty21a ini menunjukkan kenaikan titer antibodi O IgG di dalam serum orang yang telah diberi vaksinasi. Kenaikan titer antibodi O IgG tergantung dosis vaksin yang diberikan, satu kali, dua kali atau tiga kali dalam satu minggu. Meskipun serum antibodi $O$ bukan satu-satunya mekanisme pertahanan yang diberikan oleh galur yang sudah dilemahkan ini, namun jelas berkaitan erat dengan proteksi terhadap infeksi Salmonella typhi (27).

Pada penelitian terdahulu tentang Uji Hambat Adhesi In vivo, imunisasi per oral protein AdhO36 + CTB telah memberikan hasil yang sangat bermakna. Hal ini ditunjukkan dengan pertumbuhan koloni yang tidak berarti pada medium BSA (bismuth sulfite agar), yang merupakan gambaran hambatan adhesi yang sangat bermakna pada enterosit mencit Balb/c (9). Sedangkan pada penelitian ini telah dapat dibuktikan bahwa protein AdhO36 mampu menginduksi S-IgA yang sangat bermakna. Hal ini menunjukkan bahwa protein AdhO36 merupakan imunogen mukosal poten yang mampu membangkitkan respons imun mukosal dengan terbentuknya SIgA protektif yang dapat menghambat proses adhesi sebagai tahap awal proses infeksi, pada enterosit mencit Balb/c.

\section{KESIMPULAN}

Dari hasil penelitian dan pembahasan tersebut diatas dapat disimpulkan bahwa :

1. Protein AdhO36 Salmonella typhi adalah imunogen mukosal yang mampu menginduksi respons imun mukosal protektif, yaitu dengan membentuk secretory- $\lg A$ (S-lgA) yang sangat bermakna untuk menghambat atau memproteksi proses adhesi dan kolonisasi Salmonella typhi pada enterosit mencit Balb/c.

2. Protein AdhO36 Salmonella typhi apabila diberikan per oral pada mencit Balb/c juga mampu menginduksi respons imun humoral sistemik dengan membentuk IgG serum.

\section{SARAN}

1. Perlu dilakukan penelitian lanjutan tentang generalisasi Salmonella typhi atas kepemilikannya terhadap protein Adh036. Penelitian dapat dilakukan secara langsung terhadap galur Salmonella typhi yang ada, maupun secara tidak langsung berdasarkan kesesuaian antibodi yang terbentuk pada penderita-penderita demam tifoid terhadap protein AdhO36.

2. Telah terbukti bahwa protein AdhO36 Salmonella typhi adalah imunogen mukosal yang poten pada mencit Balb/c. Selanjutnya perlu dipikirkan dan diteliti lebih lanjut kemungkinan protein tersebut diuji cobakan kepada manusia.

\section{DAFTAR KEPUSTAKAAN}

1. Pang, T., Koh, C.L., Puthucheary, S.D., Typhoid Fever: Strategies for the 90's. Singapore: World Scientific. 1992.

2. Murphy, J.R., Grez, L., Immunogenicity of Salmonella typhi Ty21a vaccine for young children. Infect Immun. 1991: 59: 4291-4293.

3. Nataro, J.P., and Levine, M.M., Enteric Bacterial Vaccine, in: Ogra, P.L., Mestecky, J., Lamm, M.E., Strober, W., Bienenstock, J., McGhee, J.R., Mucosal Immunology $2^{\text {nd }}$ ed, Academic Press. 1999: 851 - 865.

4. Salyers, A.A., and Whitt, D.D., Bacterial Pathogenesis: a molecular approach. Washington DC: American Society for Microbiology Press. 1994: 30-41, 229-241.

5. Todar, K., Bacteriology 330 Lecture Topics: Colonization and Invasion. University of Wisconsin Department of Bacteriology. 1997.

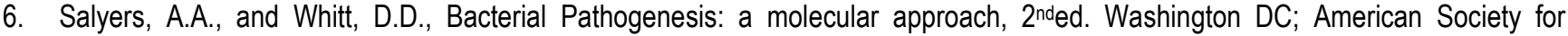
Microbiology Press. 2002: 93-94, 115-126

7. Henahan, S., E.coli vaccine; Science Update. 1997. 
Hal.

8. Michalek, Suzanne, M., Childers, Noel, K., Dertzbaugh, Mark, T., Vaccination Strategies for Mucosal Pathogens, in Virulence Mechanisms of Bacterial Pathogens, $2^{\text {nd }}$ ed., American Society for Microbiology, Washington,D.C. 1995: 269-301.

9. Santoso, S., Protektivitas in vivo protein Adh036 Salmonella typhi isolat Malang pada mencit Balb/c, Majalah Kedokteran Universitas Brawijaya Malang. 2002: 8(3): 51-59

10. McGhee, J.R., Lamm, M.E., Strober, W., Mucosal Immune Responses : An Overview in Ogra, P.L., Mestecky, J., Lamm, M.E., Strober, W., Bienenstock, J., McGhee, J.R., Mucosal Immunology 2nd ed, Academic Press. 1999: 485 - 506.

11. Finegold, S.M., Barron, E.J., Bailey and Scott's Diagnostic Microbiology, $7^{\text {th }}$ ed. CV Mosby Company, USA. 1986: 682, 862, 863, 879.

12. Ehara, M., Ishibashi, M., Ichinose, Y., Iwanaga, M., Shimotori, S., Naito, T., Purification and partial characterization of fimbriae of Vibrio cholerae 0-1, Vaccine. 1986: 5: 283-286.

13. Sumarno, Karakterisasi Molekuler Protein Adesi Vibrio cholerae 01 M094V dan Protein Reseptornya pada Sel Epitel Usus Halus Tikus Putih (Wistar), Studi Patogenesis Vibrio cholerae 01 M094V. Disertasi Program Pasca Sarjana Universitas Airlangga Surabaya. 2000.

14. Dhaenens, L., Szczebara, F., Husson, M.O., Identification, Characterization and Immunogenicity of Lactoferrin-Binding Protein from Helicobacter pylori, Infect Immun. 1997: 65 (5): 514-518.

15. Laemli, U.K., Cleavage of Structural Protein during the Assembly of the Head of Bacteriophage T4, Nature. 1970: 227: 680-686.

16. Hernandez, A.M., Gavilanes-Parra, S., Chavez-Berrocal, M., Molina-Lopez, J., Cravioto, A., Binding of Diarrheagenic Escherichia coli to 32 to 33 Kilodalton Human Intestinal Brush Border Proteins. Infect Immun. 1997: 65: 4494-4501.

17. Strober, W., and Fuss, I.J., The Mucosal Immune System in: Stites DP, Terr Al, Parslow TG Medical Immunology, 9th ed. Appleton \& Lange. 1997: 196-209.

18. Elson, C.O., and Dertzbaugh, M.T., Mucosal Adjuvants in: Ogra, P.L., Mestecky, J., Lamm, M.E., Strober, W., Bienenstock, J., McGhee, J.R., Mucosal Immunology $2^{\text {nd }}$ ed, Academic Press. 1999: 817 - 838.

19. Elson, C.O., Cholera toxin as a Mucosal Adjuvant, in Ogra, P.L., Lamm, M.E., Bienenstock, J., Mestecky, J., Strober, W., McGhee, J.R., Mucosal Vaccine, Academic Press. 1996: 59 - 72.

20. Mestecky, J., McGhee, J.R., Immunoglobulin A (IgA): Molecular and Cellular Interactions Involved in IgA Biosynthesis and Immune response. Adv.Immunol. 1987: 40: 153 - 245.

21. Mestecky, J., Moro, I., Underdown, B.J., Mucosal Immunoglobulins in: Ogra, P.L., Mestecky, J., Lamm, M.E., Strober, W., Bienenstock, J., McGhee, J.R., Mucosal Immunology, $2^{\text {nd }}$ ed., Academic Press. USA. 1999: 133 - 152.

22. Jackson, R.J., Fujihashi, K., Xu-Amanao, J., Kiyono, H., and McGhee, J.R., Optimizing Oral Vaccines: Induction of Systemic and Mucosal B cell and Antibody Responses to Tetanus Toxoid by use of Cholera Toxin as Adjuvant, Infect Immun. 1993: 61: 4272 4279.

23. Snider, D.P., Marshall, J.S., Perdue, M.H., and Liang, H., Production of IgE Antibody and Allergic Sensitization of Intestinal and Pheripheral Tissues after Oral Immunization with Protein Ag and Cholera toxin, J.Immunol. 1994: 153: 647 - 657.

24. Abbas, Abul, K., Lichtman, Andrew, H., Pober, Jordan, S., Cellular and Molecular Immunology, $4^{\text {th }}$ ed. W.B. Saunders Company. 2000: 199, 331 - 333.

25. Janeway, C.A., Travers, P., Walport, M., Capra, J.D., Immunobiology, The Immune System in Health and Disease $4^{\text {th }}$ ed., Elsevier Science Ltd/Garland Publishing. 1999: 314 - 316.

26. Bouvet, J.P., and Fischetti, V.A., Diversity of Antibody-Mediated Immunity at the Mucosal Barrier. Infect Immun. 1999: 67: 26872691.

27. Levine, M.M., and Sztein, M.B., Human Mucosal Vaccines for Salmonella typhi Infections, in: Kiyono H, Ogra PL, McGhee JR, Mucosal Vaccines. Academic Press, Inc. USA. 1996: 201 - 211.

Maj. Kedok. Unibraw Vol. XIX, No.2, Agustus 2003 